\title{
Similar Peptides from Two $\beta$ Cell Autoantigens, Proinsulin and Glutamic Acid Decarboxylase, Stimulate T Cells of Individuals at Risk for Insulin- Dependent Diabetes
}

\author{
George Rudy,* Natalie Stone,* Leonard C. Harrison,* \\ Peter G. Colman, ${ }^{\dagger}$ Peter McNair, ${ }^{\dagger}$ Vladimir Brusic,* \\ Michelle B. French,* Margo C. Honeyman, ${ }^{*}$ Brian Tait, $^{+}$ \\ and Andrew M. Lew* \\ *The Walter and Eliza Hall Institute of Medical Research, Melbourne, \\ Australia \\ ${ }^{\dagger}$ The Royal Melbourne Hospital, Melbourne, Australia
}

\begin{abstract}
Background: Insulin (1) and glutamic acid decarboxylase (GAD) (2) are both autoantigens in insulin-dependent diabetes mellitus (IDDM), but no molecular mechanism has been proposed for their association. We have identified a 13 amino acid peptide of proinsulin (amino acids 24-36) that bears marked similarity to a peptide of GAD65 (amino acids 506-518) (G. Rudy, unpublished). In order to test the hypothesis that this region of similarity is implicated in the pathogenesis of IDDM, we assayed $\mathrm{T}$ cell reactivity to these two peptides in subjects at risk for IDDM.

Materials and Methods: Subjects at risk for IDDM were islet cell antibody (ICA)-positive, first degree relatives of people with insulin-dependent diabetes. Peripheral blood mononuclear cells from 10 pairs of at-risk and
\end{abstract}

HLA-DR matched control subjects were tested in an in vitro proliferation assay.

Results: Reactivity to both proinsulin and GAD peptides was significantly greater among at-risk subjects than controls (proinsulin; $p<0.008$; GAD: $p<0.018$ ). In contrast to reactivity to the GAD peptide, reactivity to the proinsulin peptide was almost entirely confined to the at-risk subjects.

Conclusions: This is the first demonstration of $\mathrm{T}$ cell reactivity to a proinsulin-specific peptide. In addition, it is the first example of reactivity to a minimal peptide region shared between two human autoimmune diseaseassociated self antigens. Mimicry between these similar peptides may provide a molecular basis for the conjoint autoantigenicity of proinsulin and GAD in IDDM.

\section{INTRODUCTION}

The selective destruction of $\beta$ cells in the pancreatic islets leading to insulin deficiency and insulin-dependent diabetes mellitus (IDDM) is considered to be an autoimmune process mediated primarily by autoreactive $\mathrm{T}$ cells (reviewed in Ref. 3). Thus, in rodent models of IDDM, the "insulitis" lesion of the islets comprises a mixed

Address correspondence and reprint requests to: George Rudy, Burnet Clinical Research Unit, The Walter and Eliza Hall Institute of Medical Research, Post Office, Royal Melbourne Hospital, Victoria 3050, Australia. mononuclear cell infiltrate, the disease can be transferred by $\mathrm{T}$ cells to naive animals, and disease expression is prevented by a variety of anti-T cell agents (reviewed in Ref. 3). In humans with recently diagnosed IDDM, examination of pancreas tissue obtained at postmortem (4-6) or by needle biopsy $(7,8)$ reveals a similar though less florid insulitis lesion. Without immunosuppression, insulitis recurs in pancreas isografts between HLA-identical twins (9). The effect of the immunosuppressive agents, cyclosporine and azathioprine, to induce and/or prolong remissions after diagnosis of IDDM (reviewed in Ref. 


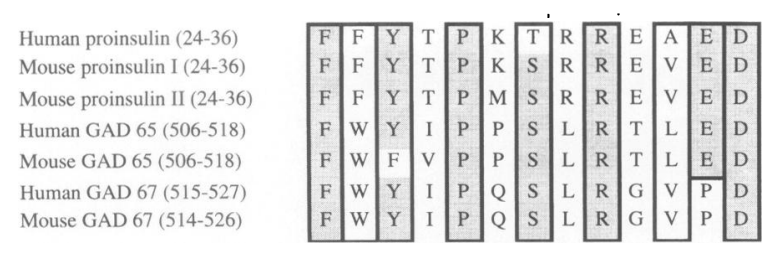

FIG. 1. Region of similarity between proinsulin and GAD

Similarities are boxed; identities within boxes are shaded. The $C$ terminus of the insulin $B$ chain and the cleavage site of the proinsulin convertase are indicated by the vertical line and arrow, respectively.

10) provides further, indirect, evidence of the autoimmune nature of $\beta$ cell destruction. Finally, the presence of circulating IgG autoantibodies and autoreactive $\mathrm{T}$ cells to islet antigens reflects underlying $\beta$ cell autoimmunity (3). However, the molecular events that trigger and sustain $\beta$ cell autoimmunity in humans have not yet been defined.

A number of molecules present in the pancreatic islets might initiate and/or perpetuate $\beta$ cell autoimmunity. Of these, only insulin and glutamic acid decarboxylase (GAD) meet clinical and, in the case of the nonobese diabetic (NOD) mouse, direct experimental criteria for a pathogenic role (11). Certainly, insulin is the only known $\beta$ cell-specific autoantigen in IDDM, and mounting evidence suggests its involvement in human diabetes. Autoantibodies to its parent, proinsulin, have also been found in IDDM (12). Prospective studies of the offspring of IDDM families, by our laboratory and elsewhere (13), suggest that insulin autoantibodies (IAA) are the earliest detectable marker of $\beta$ cell autoimmunity.

Several studies have also demonstrated specific T cell reactivity to islet antigens. Whole islets stimulate the proliferation of $\mathrm{T}$ cells from subjects at-risk for or with clinical IDDM significantly more than autoimmune or HLA-matched healthy control subjects $(14,15)$. GAD peptides or recombinant GAD also stimulate $T$ cells in these IDDM groups (16-18). However, attempts to demonstrate T cell reactivity to insulin have been largely unsuccessful in humans (15), although insulin is a target for islet-reactive T cells in mice (19). Similar studies with proinsulin have not been published.

We have observed that a short region (13 amino acids) in the sequence of proinsulin bears marked similarity (six identical, three conserved residues) to a sequence from GAD (Fig. 1). This similarity is found in both GAD isoforms (GAD65 and GAD67), as well as in the mouse GAD enzymes and proinsulins. It is notable that this region lies within a portion of human GAD65 (amino acids 473-543) shown to be immunodominant for $\mathrm{T}$ cells of IDDM patients (18). As well, it is largely included in one of the two mouse GAD65 peptides (amino acids 509-528) that are the earliest to be recognized by $\mathrm{T}$ cells in the NOD model of IDDM (20). Finally, the proinsulin sequence spans the cleavage site (Arg 32-Glu 33) of the PC 1/3 convertase (21), which separates the $C$ peptide from the insulin $B$ chain. This region is therefore absent from the mature insulin molecule and would not have been previously tested in assays based on insulin or its peptide fragments. The present study was designed to address whether this region of similarity might be a focus of $\mathrm{T}$ cell autoreactivity in IDDM, thereby providing a molecular basis for the observation of shared autoimmunity to GAD and (pro)insulin.

\section{MATERIALS AND METHODS}

\section{Subjects}

Subjects at-risk for IDDM were from the Melbourne Prediabetes Family Study. Each was entered on the basis of having at least one first degree relative with IDDM, and islet cell antibody (ICA) $\geq 20$ JDF units and/or IAA $\geq 100$ $\mathrm{nU} / \mathrm{ml}$ (Table 1). All had normal fasting blood glucose and glycated hemoglobin, and have had repeat antibody and metabolic tests at six monthly intervals. Control subjects were HLA-DR matched, asymptomatic, and without history of IDDM.

All subjects gave informed, signed consent, and the study was approved by the Ethics Committees of the Royal Melbourne Hospital and the Walter and Eliza Hall Institute of Medical Research.

\section{HLA Typing and Assays of ICA, IAA, GAD $A b$, and FPIR}

HLA TYPING: HLA class I (A,B,C) and HLA class II (DR,DQ) typing was performed using enriched populations of $\mathrm{T}$ and $\mathrm{B}$ lymphocytes, respectively. The cells were isolated from anticoagulated blood using magnetic beads coated with monoclonal antibodies to CD8 (class I) or a monomorphic determinant on the class II $\beta$ chain (class II) (Dynal). The enriched cell populations were typed by an internationally stan- 


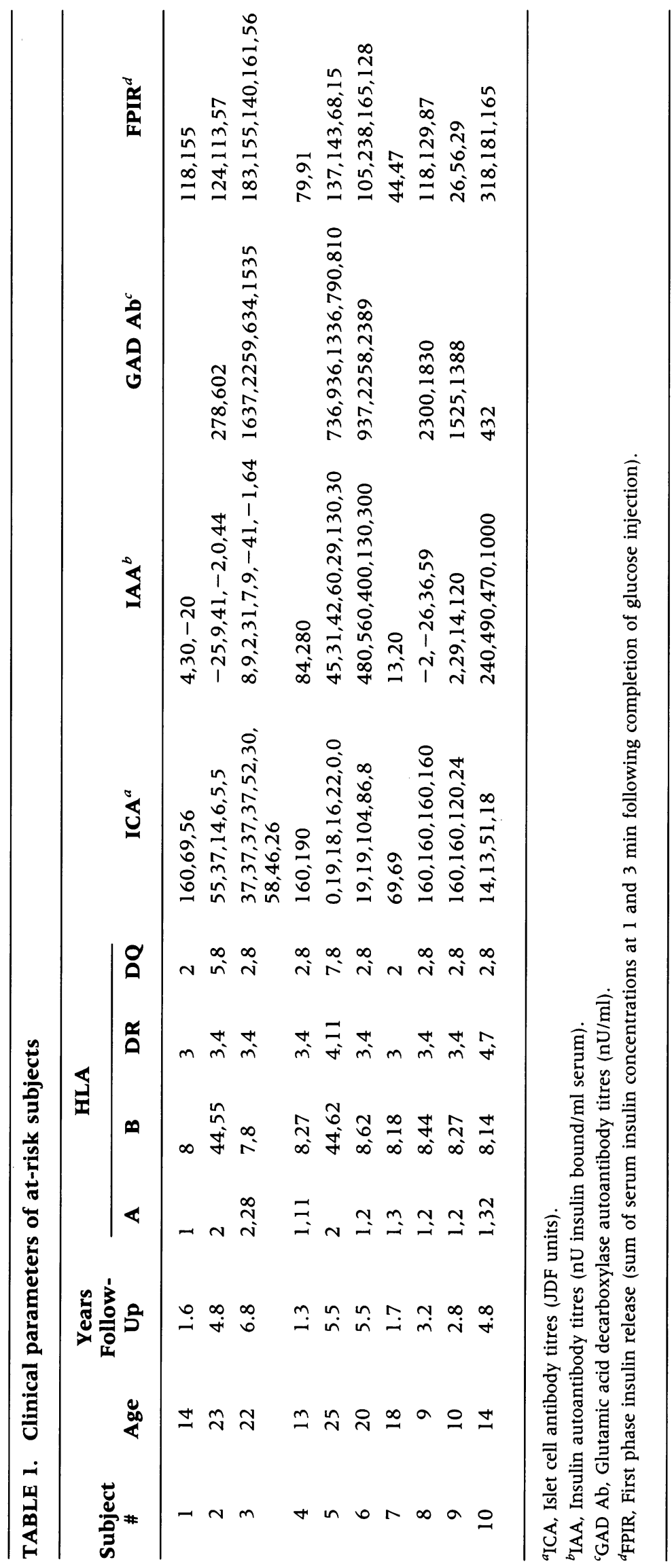


dardized microlymphocytotoxicity assay using a battery of 240 allosera for class I and 120 allosera for class II.

ANTIBODY ASSAYS: ICA were assayed using indirect immunofluorescence on blood group $\mathrm{O}$ donor pancreas. Titres, in JDF units, were determined by doubling dilution of positive sera and comparison with standard sera run in each assay. The assay has been included in all International Diabetes Workshops and proficiency programs.

IAA were assayed by a radiobinding method which has been internationally standardized. The upper limit for normal control sera is $40 \mathrm{nU}$ insulin bound $/ \mathrm{ml}$ serum.

GAD antibodies were assayed by immunoprecipitation of GAD enzymatic activity from piglet brain extract (22). The mean plus 3 SD of 72 healthy subjects, $460 \mathrm{nU} / \mathrm{ml}$, was used to define the normal range.

FIRST PHASE INSULIN RELEASE (FPIR): FPIR was calculated as the sum of serum insulin concentrations at 1 and $3 \mathrm{~min}$ following the completion of intravenous glucose $(0.5 \mathrm{~g} / \mathrm{kg}$ body $\mathrm{wt})$ injection over 3 min.

\section{$T$ cell proliferation assay:}

Blood was drawn from paired at-risk and HLADR-matched control subjects at the same time (within $30 \mathrm{~min}$ ) on the same day and processed similarly to reduce the effects of diurnal variation and handling artefacts. Peripheral blood mononuclear cells were isolated from heparinized whole blood by Ficoll-Paque (Pharmacia Biotech, Uppsala, Sweden) density centrifugation, washed and resuspended in RPMI 1640 medium (Gibco, Grand Island, NY, USA) containing $20 \mathrm{mM}$ Hepes (CSL Ltd., Melbourne, Australia), $10^{-5} \mathrm{M}$ 2-mercaptoethanol (BDH, Poole, England), penicillin $(100 \mathrm{U} / \mathrm{ml})$, streptomycin $(100 \mu \mathrm{g} / \mathrm{ml})$ and $10 \%$ autologous plasma. Aliquots of $200 \mu \mathrm{l}(2 \times$ $10^{5}$ cells) were transferred into wells of a 96well, round-bottomed plate (Falcon, Lincoln Park, NJ, USA) and incubated in replicates of six with the following peptides at final concentrations of 10,2 , and $0.4 \mu \mathrm{g} / \mathrm{ml}$ : human GAD65 (amino acids 506-518), human proinsulin (amino acids 24-36) (synthesized using an Applied Biosystems Model 431A Synthesizer [ABI, Foster City, CA, U.S.A.]), and an irrelevant control peptide (CRFDPQFALTNIAVRK) (Macromolecular Resources, Fort Collins, CO). Tetanus toxoid (CSL Ltd.) at final concentrations of $1.8,0.18$, and 0.018
$\mathrm{LfU} / \mathrm{ml}$ was used as a positive control. Twelve "autologous only" wells containing cells but without antigen were included as the background control. Plates were incubated at $37^{\circ} \mathrm{C}$ in a $5 \% \mathrm{CO}_{2}$ humidified incubator for 6 days; $0.25 \mu \mathrm{Ci}$ of $\left[{ }^{3} \mathrm{H}\right]$-thymidine (ICN) was added to each well for the last $6 \mathrm{hr}$. The cells were then harvested onto glass fiber filters and incorporated radioactivity measured by $\beta$-particle counting (Packard Model 2000 Liquid Scintillation Counter). The level of cellular proliferation was expressed as the delta score (DS, mean counts per minute $[\mathrm{cpm}]$ incorporated in the presence of antigen, minus the mean cpm of the "autologous only" wells).

\section{RESULTS}

The mean age of the at-risk subjects was 17 years and mean period of follow-up was 3.8 years. All subjects were either HLA-DR3 or -DR4 positive, and five had the high-risk HLA-DR 3,4; DQ 2,8 type. All had ICA $\geq 20$ JDF units on at least one occasion and eight had two or more antibodies positive. Two subjects had first phase insulin release $<50 \mathrm{ml}$ at first test; in three others, FPIR has fallen by more than $50 \%$ during follow-up. By accepted criteria, this group of relatives is at very high risk for progression to IDDM.

$\mathrm{T}$ cell proliferative responses to the similar 13-mer peptides from proinsulin and GAD were compared for 10 pairs of HLA-DR-matched atrisk and control subjects. HLA-DR matching was thought to be important not only because of the specificity of peptide binding to MHC class II alleles but also because of the known association between MHC class II and IDDM. Therefore, T cell responses would reflect IDDM rather than MHC specificity. Responses to the highest concentration of either peptide were significantly (proinsulin: $p<0.008$; GAD: $p<0.018-W i l-$ coxon one-tailed paired analysis) greater among at-risk than control subjects (Table 2 ). Reactivity to the proinsulin sequence was confined almost entirely to at-risk subjects, whereas some controls also responded to the GAD peptide (Table 2 , Fig. 2). Both groups responded similarly to tetanus, and no subject reacted to the unrelated control peptide.

For six of these pairs (\#1, 2, 3, 5, 6, and 7), the assay was performed on a separate occasion, but using twice as many cells $\left(4 \times 10^{5}\right.$ per well). Exhaustion of the media resulted in unreliable results in three cases. In two of the other three (\#5 and 6), the results were consistent with those 


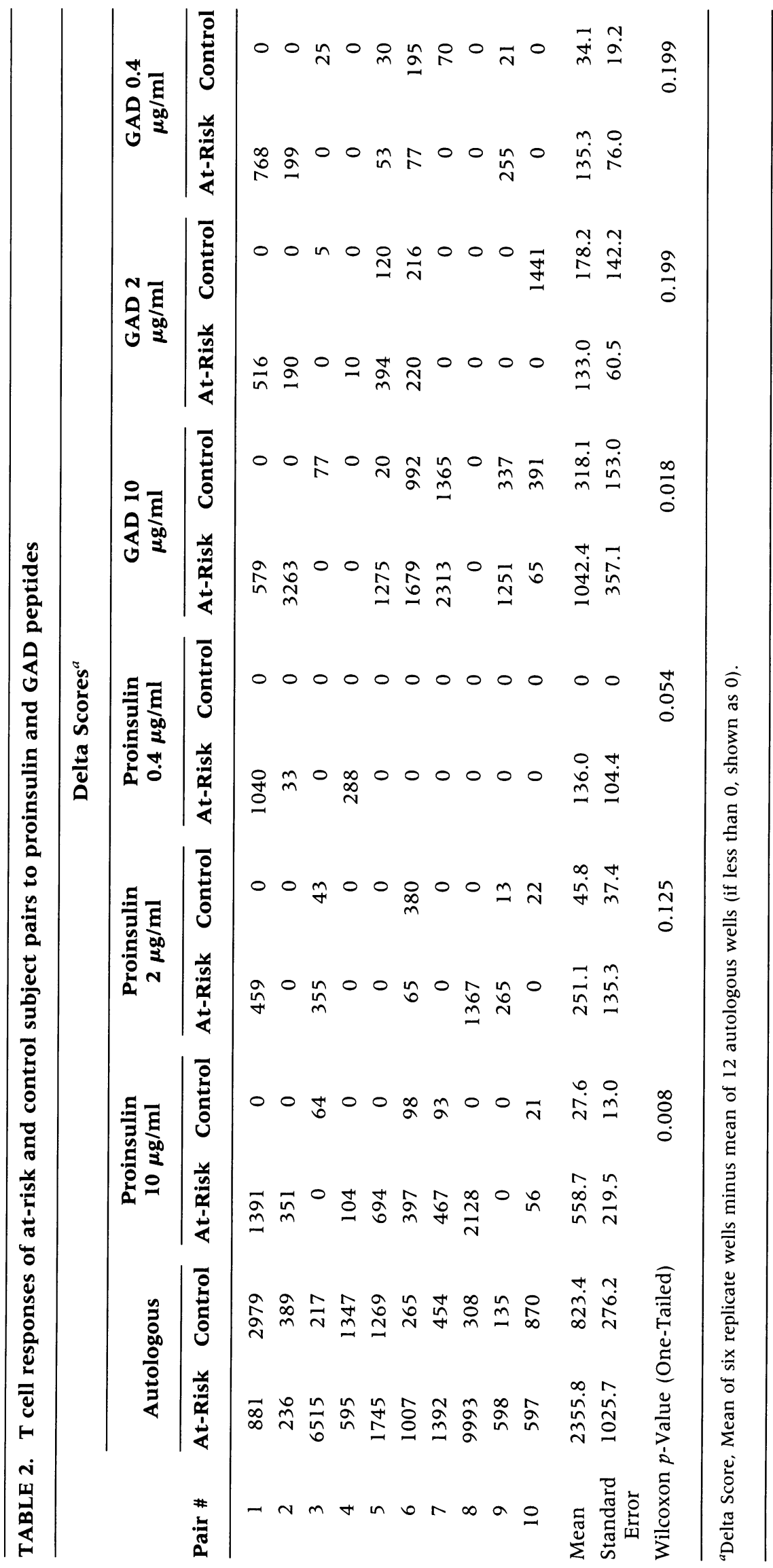



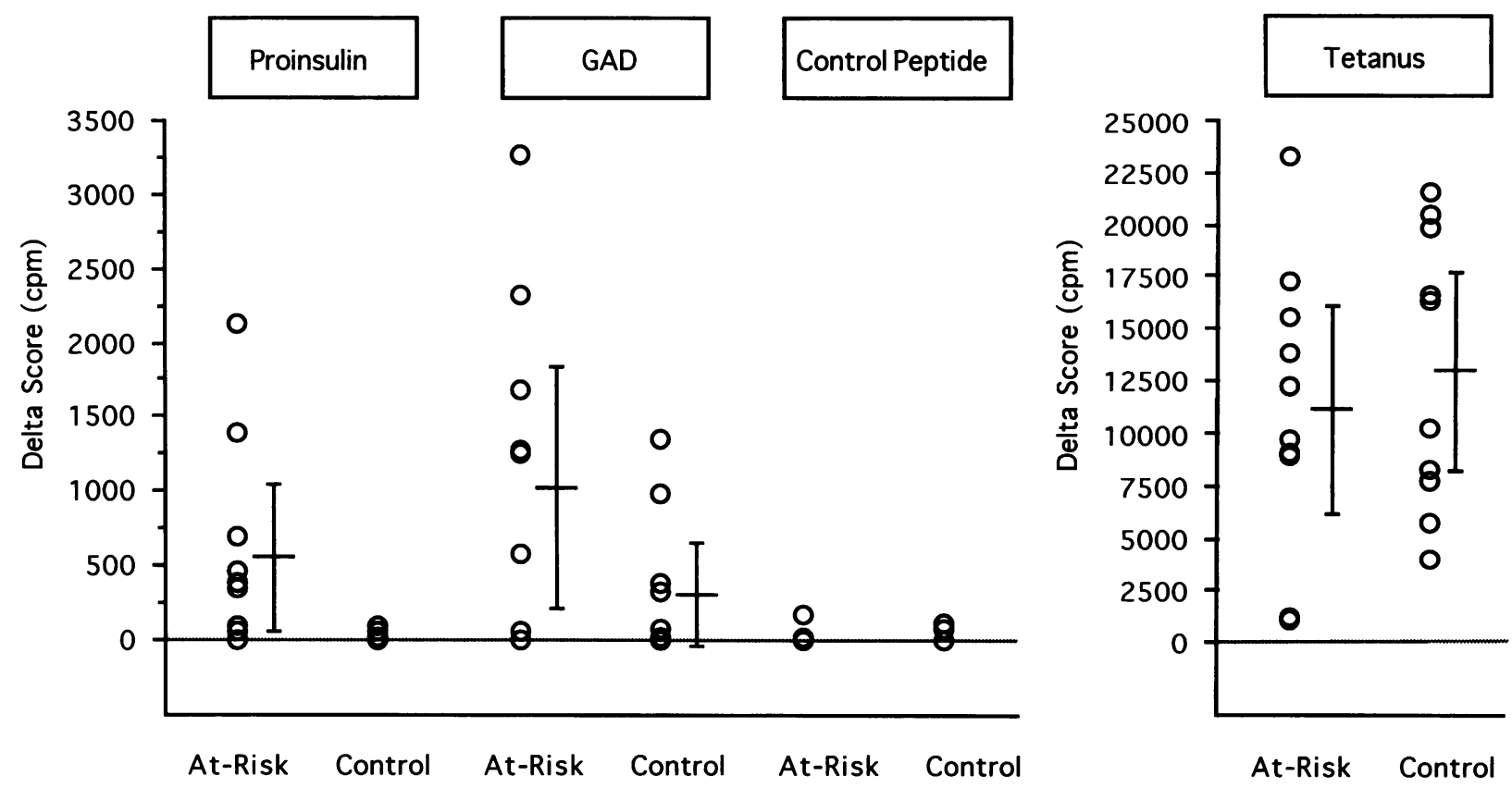

FIG. 2. Proliferation of peripheral blood $\mathrm{T}$ cells, as measured by $\left[{ }^{3} \mathrm{H}\right]$-thymidine incorporation, in response to the antigens: proinsulin peptide $10 \mu \mathrm{g} / \mathrm{ml}$, GAD peptide $10 \mu \mathrm{g} / \mathrm{ml}$, control peptide $10 \mu \mathrm{g} / \mathrm{ml}$, and tetanus toxoid $1.8 \mathrm{LfU} / \mathrm{ml}$

Error bars indicate mean and $95 \%$ confidence interval.

tabulated here, while in the third (\#3) the at-risk subject displayed greater reactivity to both antigens at the higher cell number. These results indicate that there is probable reproducibility between tests, although a larger number of subjects using similar cell numbers would be required to confirm this. Similarly, a larger number of subjects is necessary to determine whether there is an association between the observed $\mathrm{T}$ cell reactivity and clinical parameters. Long-term follow-up will be required to determine whether this reactivity has predictive value for development of IDDM.

\section{DISCUSSION}

This is the first published demonstration of $\mathrm{T}$ cell reactivity to a proinsulin-specific peptide. The absence of this sequence from the mature insulin molecule, due to processing by the PC $1 / 3$ convertase enzyme, may account for the previously encountered difficulty in finding insulin-reactive $\mathrm{T}$ cells in at-risk or recently diagnosed subjects (15). A number of papers not only have documented elevated proinsulin levels in early-onset IDDM and at-risk subjects (23-27), but also have reported proinsulin autoantibodies $(12,28,29)$.

To our knowledge, $\mathrm{T}$ cell reactivity to similar sequences from two major autoantigens has not been previously reported. This finding suggests that molecular mimicry between these peptides could be responsible for the conjoint immunogenicity of their parent molecules. If so, this may be the first example of molecular mimicry at the $\mathrm{T}$ cell level in human disease. "Antigen mimicry" via a short sequence of shared residues can cause organ-specific autoimmune disease in an animal model (30). In that case, immunization with a peptide from the murine nicotinic acetylcholine receptor $\delta$ chain (ACR $\delta$ ), which shares four amino acids with a peptide from murine ovarian zona pellucida glycoprotein ZP3, resulted in murine oophoritis and IgG autoantibodies to the zona pellucida. It is remarkable that polyalanine peptides containing only the four shared residues were similarly able to induce disease. The peptide sequences examined in the present study have even greater similarity. $T$ cell reactivity to similar sequences in proinsulin and GAD provides a potential means for immunoreactivity (both humoral and cellular) to spread from one of these autoantigens to the other, assuming that processing of the parent protein generates the mimic peptide which can then be bound and presented by an appropriate HLA molecule.

The MHC association with IDDM is well es- 
tablished (reviewed in Ref. 31). In humans, although certain alleles are known to impart higher risk than others, no single allele is essential to disease development. In the NOD mouse, both the MHC class II I-A $\mathrm{A}^{\mathrm{g} 7}(32)$ and the class I $\mathrm{H}-2 \mathrm{~K}^{\mathrm{d}}$ (33) have been independently implicated. The observed region of similarity of these peptides extends to both mouse GADs and proinsulins (Fig. 1), and contains both a XYX$\operatorname{XXXXXX(L/V)~motif~for~binding~to~} K^{d}(34)$ as well as the $(+) \mathrm{XXX}(-)$ motif present in most of the peptides so far reported to bind I-A $\mathrm{A}^{\mathrm{g7}}(32,35,36)$. Both the proinsulin and GAD peptides bind with moderate to high affinity to I-A $\mathrm{A}^{\mathrm{g7}}$ and to the highrisk allele HLA-DR $(\alpha, \beta 1 * 0401)$ (L. C. Harrison and M. C. Honeyman, unpublished).

Others have found the $\mathrm{T}$ cell response to GAD65 in IDDM to be largely directed to the $\mathrm{COOH}$-terminal region $(18,17)$, which includes the peptide we have studied here, although they neither examined it specifically nor employed HLA-matched controls. This region also appears to be a focus of humoral immunity to GAD in $\operatorname{IDDM}(37,38)$. The phenomenon of $\mathrm{B}$ and $\mathrm{T}$ cell epitope concordance has been noted in several other instances, and may be indicative of a role for antibody in amplifying or focusing the immune response. Examples include epitopes from the inner lipoyl domain of PDC-E2 in primary biliary cirrhosis (39) and from poliovirus (40). It is interesting to speculate on the potential significance of this overlap at a molecular level of cellular and humoral responses. While initial breaking of $\mathrm{T}$ cell tolerance, due to aberrant processing and presentation of self antigens or mimicry with foreign pathogen, might seem a likely route to autoimmunity, the alternative direction of spread from activated $\mathrm{B}$ to $\mathrm{T}$ cell has also been described (41). In either case, careful analysis of linear sequence similarity between known autoantigens may provide clues to the genesis of $\mathrm{T}$ cell immunity underlying disease.

That the proinsulin epitope spans the natural convertase cleavage site may be significant in the pathogenesis of IDDM. Perhaps an early event in this pathogenesis involves abnormal processing of proinsulin, resulting in an unusual intermediate or an unusual amount of an intermediate. In individuals with a permissive $\mathrm{MHC}$, this intermediate might subsequently be processed and presented by APCs resident in the islets to $\mathrm{T}$ cells not tolerant of this normally "cryptic" epitope. An alternative scenario is direct presentation by the $\beta$ cell itself. Class II MHC and accessory molecules like ICAM-I can be induced in human islet cells exposed to immuno-inflammatory cytokines $(42,43)$, but it is arguable whether the $\beta$ cell thereby acquires the functionality of an APC. There is some evidence that autoimmunity to GAD precedes that to insulin in NOD mice $(20,44)$. We and others have found that normal individuals can have $T$ cell reactivity to GAD (cf. proinsulin). One could speculate that while many individuals have $T$ cells reactive to GAD, these are initially nonpathogenic. Subsequent expansion of some of these $\mathrm{T}$ cell clones that are cross-reactive with proinsulin may produce activated clones with increased pathogenicity (e.g., due to increased adhesion molecules, costimulator molecules, cytokine production, etc.) and might provide the trigger for insulitis. This hypothesis predicts that tolerization regimens with either GAD or proinsulin should prevent disease onset.

\section{ACKNOWLEDGMENTS}

The authors express their appreciation to Margaret Thompson for secretarial assistance and thank the Victorian Health Promotion Foundation for their support. GR is a recipient of a National Health and Medical Research Council fellowship. MBF was a recipient of a Medical Research Council of Canada fellowship.

\section{REFERENCES}

1. Palmer JP, Asplin CM, Clemons P, et al. (1983) Insulin antibodies in insulin-dependent diabetics before insulin treatment. Science 222(4630): 1337-1339.

2. Baekkeskov S, Aanstoot HJ, Christgau S, et al. (1990) Identification of the $64 \mathrm{~K}$ autoantigen in insulin-dependent diabetes as the GABA-synthesizing enzyme glutamic acid decarboxylase. Nature 347(6289): 151-156.

3. Honeyman MC, Harrison LC. (1993) The immunologic insult in type 1 diabetes. Springer Semin. Immunopathol. 14(3): 253-274. Review.

4. Bottazzo GF, Dean BM, McNally JM, MacKay EH, Swift PGF, Gamble DR. (1985) In situ characterization of autoimmune phenomena and expression of HLA molecules in the pancreas in diabetic insulitis. N. Engl. J. Med. 313(6): 353-360.

5. Foulis AK, McGill M, Farquharson MA. (1991) Insulitis in type 1 (insulin-dependent) diabetes mellitus in man-Macrophages, lymphocytes, and interferon-gamma containing cells. J. Pathol. 165(2): 97-103. 
6. Hanninen A, Jalkanen S, Salmi M, Toikkanen S, Nikolakaros G, Simell O. (1992) Macrophages, T cell receptor usage, and endothelial cell activation in the pancreas at the onset of insulin-dependent diabetes mellitus. J. Clin. Invest. 90(5): 1901-1910.

7. Hanafusa T, Miyazaki A, Miyagawa J, et al. (1990) Examination of islets in the pancreas biopsy specimens from newly diagnosed type 1 (insulin-dependent) diabetic patients. Diabetologia 33(2): 105-111.

8. Itoh N, Hanafusa T, Miyazaki A, et al. (1993) Mononuclear cell infiltration and its relation to the expression of major histocompatibility complex antigens and adhesion molecules in pancreas biopsy specimens from newly diagnosed insulin-dependent diabetes mellitus patients. J. Clin. Invest. 92(5): 2313-222.

9. Sibley RK, Sutherland DER, Goetz F, Michael AF. (1985) Recurrent diabetes mellitus in the pancreas iso- and allograft. A light and electron microscopic and immunohistochemical analysis of four cases. Lab. Invest. 53(2): 132-144.

10. Dupre J, Stiller CR. (1989) Summary and critical evaluation of immunosuppression trials in recent-onset type 1 diabetes. In: Andreani D, Kolb H, Pozzilli P (eds). Immunotherapy of Type 1 Diabetes. John Wiley $\&$ Sons, London, United Kingdom, pp. 125-136.

11. Harrison LC. (1992) Islet cell antigens in insulin-dependent diabetes: Pandora's box revisited [see comments]. Immunol. Today 13(9): 348-352. Review.

12. Bohmer K, Keilacker H, Kuglin B, et al. (1991) Proinsulin autoantibodies are more closely associated with type 1 (insulin-dependent) diabetes mellitus than insulin autoantibodies. Diabetologia 34(11): 830-834.

13. Ziegler AG, Hillebrand B, Rabl W, et al. (1993) On the appearance of islet associated autoimmunity in offspring of diabetic mothers: a prospective study from birth. Diabetologia 36(5): 402-408.

14. Harrison LC, De Aizpurua H, Loudovaris T, et al. (1991) Reactivity to human islets and fetal pig proislets by peripheral blood mononuclear cells from subjects with preclinical and clinical insulin-dependent diabetes. Diabetes 40(9): 1128-1 133.

15. Harrison LC, Chu SX, DeAizpurua HJ, et al. (1992) Islet-reactive T cells are a marker of preclinical insulin-dependent diabetes. $J$. Clin. Invest. 89(4): 1161-1165.

16. Honeyman MC, Cram DS, Harrison LC. (1993) Glutamic acid decarboxylase 67-reac- tive T cells: A marker of insulin-dependent diabetes. J. Exp. Med. 177(2): 535-540.

17. Atkinson MA, Bowman MA, Campbell L, Darrow BL, Kaufman DL, Maclaren NK. (1994) Cellular immunity to a determinant common to glutamate decarboxylase and coxsackie virus in insulin-dependent diabetes. J. Clin. Invest. 94(5): 2125-2129.

18. Lohmann T, Leslie R, Hawa M, Geysen M, Rodda SM. (1994) Immunodominant epitopes of glutamic acid decarboxylase 65 and 67 in insulin dependent diabetes mellitus. Lancet 343(8913): 1607-1608.

19. Wegmann DR, Norbury-Glaser M, Daniel D. (1994) Insulin-specific T cells are a predominant component of islet infiltrates in prediabetic NOD mice. Eur. J. Immunol. 24(8): 1853-1857.

20. Kaufman DL, Clare-Salzler M, Tian J, et al. (1993) Spontaneous loss of T-cell tolerance to glutamic acid decarboxylase in murine insulindependent diabetes. Nature 366(6450): 69-72.

21. Davidson HW, Rhodes CJ, Hutton JC. (1988) Intraorganellar calcium and $\mathrm{pH}$ control proinsulin cleavage in the pancreatic beta cell via two distinct site-specific endopeptidases. Nature 333(6168): 93-96.

22. Schmidli RS, DeAizpurua HJ, Harrison LC, Colman PG. (1994) Antibodies to glutamic acid decarboxylase in at-risk and clinical insulin-dependent diabetic subjects: Relationship to age, sex and islet cell antibody status, and temporal profile. J. Autoimmun. 7(1): $55-66$.

23. Snorgaard O, Hartling SG, Binder C. (1990) Proinsulin and C-peptide at onset and during 12 months cyclosporin treatment of type 1 (insulin-dependent) diabetes mellitus [see comments]. Diabetologia 33(1): 36-42.

24. Heaton DA, Millward BA, Gray IP, et al. (1988) Increased proinsulin levels as an early indicator of B-cell dysfunction in non-diabetic twins of type 1 (insulin-dependent) diabetic patients. Diabetologia 31(3): 182-184.

25. Hartling SG, Lindgren F, Dahlqvist G, Persson B, Binder C. (1989) Elevated proinsulin in healthy siblings of IDDM patients independent of HLA identity. Diabetes 38(10): 1271-1274.

26. Lindgren FA, Hartling SG, Persson BE, et al. (1993) Proinsulin levels in newborn siblings of type 1 (insulin-dependent) diabetic children and their mothers. Diabetologia 36(6): 560-563.

27. Spinas GA, Snorgaard O, Hartling SG, Ober- 
holzer M, Berger W. (1992) Elevated proinsulin levels related to islet cell antibodies in first-degree relatives of IDDM patients. Diabetes Care 15(5): 632-637.

28. Kuglin B, Gries FA, Kolb H. (1988) Evidence of IgG autoantibodies against human proinsulin in patients with IDDM before insulin treatment. Diabetes 37(1): 130-132.

29. Kuglin B, Halder B, Bertrams J, Gruneklee D, Gries FA, Kolb H. (1990) Proinsulin autoantibodies: association with type I diabetes but not with islet cell antibodies, insulin autoantibodies or HLA-DR type. J. Autoimmun. 3(5): 573-577.

30. Luo AM, Garza KM, Hunt D, Tung KSK. (1993) Antigen mimicry in autoimmune disease sharing of amino acid residues critical for pathogenic $\mathrm{T}$ cell activation. J. Clin. Invest. 92(5): 2117-2123.

31. Hurtenbach U, Lier E, Adorini L, Nagy ZA. (1993) Prevention of autoimmune diabetes in non-obese diabetic mice by treatment with a class II major histocompatibility complex-blocking peptide. J. Exp. Med. 177(5): 1499-1504.

32. Taki T, Nagata $M$, Ogawa $W$, et al. (1991) Prevention of cyclophosphamide-induced and spontaneous diabetes in NOD/Shi/Kbe mice by anti-MHC class I Kd monoclonal antibody. Diabetes 40(9): 1203-1209.

33. Romero P, Corradin G, Luescher IF, Maryanski JL. (1991) H-2Kd-restricted antigenic peptides share a simple binding motif. J. Exp. Med. 174(3): 603-612.

34. Reich EP, Von Grafenstein H, Barlow A, Swenson KE, Williams K, Janeway CA. (1994) Self peptides isolated from MHC glycoproteins of nonobese diabetic mice. J. Immunol. 152(5): 2279-2288.

35. Deng $H$, Apple $R$, Clare-Salzler $M$, et al. (1993) Determinant capture as a possible mechanism of protection afforded by major histocompatibility complex class II molecules in autoimmune disease. J. Exp. Med. 178(5): 1675-1680.

36. Tian J, Lehmann PV, Kaufman DL. (1994) T cell cross-reactivity between coxsackievirus and glutamate decarboxylase is associated

Contributed by G. J. V. Nossal on July 10, 1995. with a murine diabetes susceptibility allele. J. Exp. Med. 180(5): 1979-1984.

37. Butler MH, Solimena M, Dirkx R, Hayday A, De Camilli P. (1993) Identification of a dominant epitope of glutamic acid decarboxylase (GAD-65) recognized by autoantibodies in stiff-man syndrome. J. Exp. Med. 178(6): 2097-2106.

38. Richter W, Shi Y, Baekkeskov S. (1993) Autoreactive epitopes defined by diabetes-associated human monoclonal antibodies are localized in the middle and C-terminal domains of the smaller form of glutamate decarboxylase. Proc. Natl. Acad. Sci. U.S.A. 90(7): 2832-2836.

39. Shimoda $S$, Nakamura $M$, Ishibashi $H, H a-$ yashida K, Niho Y. (1995) HLA DRB4 0101restricted immunodominant $\mathrm{T}$ cell autoepitope of pyruvate dehydrogenase complex in primary biliary cirrhosis: Evidence of molecular mimicry in human autoimmune diseases. J. Exp. Med. 181(5): 1835-1845.

40. Graham S, Wang ECY, Jenkins O, Borysiewicz LK. (1993) Analysis of the human T-cell response to picornaviruses: Identification of $\mathrm{T}$ cell epitopes close to B-cell epitopes in poliovirus. J. Virol. 67(3): 1627-1637.

41. Lin RH, Mamula MJ, Hardin JA, Janeway CA. (1991) Induction of autoreactive B cells allows priming of autoreactive T cells. J. Exp. Med. 173(6): 1433-1439.

42. Campbell IL, Oxbrow L, West J, Harrison LC. (1988) Regulation of MHC protein expression in pancreatic beta-cells by interferongamma and tumor necrosis factor-alpha. Mol. Endocrinol. 2(2): 101-107.

43. Campbell IL, Cutri A, Wilkinson D, Boyd AW, Harrison LC. (1989) Intercellular adhesion molecule 1 is induced on isolated endocrine islet cells by cytokines but not by reovirus infection. Proc. Natl. Acad. Sci. U.S.A. 86(11): 4282-4286.

44. Tisch R, Yang XD, Singer SM, Liblau RS, Fugger L, McDevitt HO. (1993) Immune response to glutamic acid decarboxylase correlates with insulitis in non-obese diabetic mice. Nature 366(6450): 72-75. 